\title{
Strategy Analysis of Regional Tourism Development: Case Study of Restaurant in Barru District
}

\author{
${ }^{1}$ Rita, ${ }^{2}$ Muhammad Arifin \\ ${ }^{12}$ Politeknik Pariwisata Makassar, Indonesia 90245 \\ E-mail: ${ }^{1}$ narita.md@gmail.com ; ${ }^{2}$ arifinmuhammad77@yahoo.com
}

Received: 25 September 2020; Revised: 27 Oktober 2020; Accepted: 27 Desember 2020

\begin{abstract}
This study aims to describe the strategies used in increasing restaurant guest visits in Barru Regency. This research uses a quantitative descriptive approach. Based on the results of the study, it was found that the 4P marketing mix strategy (Price, Promotion, Place and position) was applied to the Barru district restaurant to increase guest visits, this proved effective in attracting guests to visit the restaurant. product, price, place, promotion, have shown conformity with the segmentation, targeting and positioning expected by the restaurant. For example, the products offered are varied and use quality raw materials in accordance with the positioning that the company wants to achieve as the only restaurant that uses healthy raw chicken and seafood. Apart from that the price, physical evidence and promotion are also in accordance with the targeting of young people and families, because the prices offered are still quite affordable, the place is also unique and is promoted through online media.
\end{abstract}

Keywords: Strategy: Tourism Development: Restaurants: Visitors

Link DOI : http://dx.doi.org/10.31314/pjia.9.2.132-145.2020

\section{INTRODUCTION}

The rapid business development, especially in the tourism sector today, encourages companies or organizations to optimize their resources to face competition. Competition is a challenge that must be faced by every company. Companies must prepare a strong strategy in order to maintain a competitive position amidst the competition through the determination of a clear vision and mission and work more efficiently, effectively and productively.

To promote tourism, facilities that can support it are needed, namely the hospitality industry. The existence of the hospitality industry in an area is a huge attraction for tourists, both for entertainment and for business purposes. Hospitality or hospitality is the key in winning the competition. The hospitality that is meant is not just hospitality in the sense of language, but the hospitality in question is a knowledge and art in terms of selling services, serving customers with full respect and humanity.

Serving wholeheartedly is the key / business motto in paying attention to customers, as well as fulfilling all their basic human needs, as well as selfactualization of tourists during their trip. This must be fulfilled by the hospitality business actors as good hosts and service providers. With these conditions, customers or tourists will feel satisfied, so that tourists love the business products / services we offer more, and often even make recommendations for our products to their colleagues (Syahrial \& Badollahi, 2020).

Apart from being interpreted as the concept of a verb, namely "hospitality to 
guests". Hospitality in general is also often interpreted as a "form of tourism service business" (noun / object) which is usually mentioned more specifically including accommodation, food and beverage (restaurant) businesses, attractions and businesses, cinema, games. / casino and so on. Because every business supporting tourism has become an obligation to implement hospitality in every service, it can also be called a hospitality business.

The hospitality business is not just about selling elite class hotel rooms as goods (inanimate objects), or selling delicious food that only meets the needs of the stomach. However, the hospitality business is a business that requires a soul or spirit in its operational joints. Hospitality is about how to make inanimate products come alive, so that they can directly touch the feelings of clients / tourists as humans who also have a soul (spirit). When consumers trust restaurant brands, consumers will believe the products offered are quality, good, healthy, and hygienic products. Based on this, it can be explained that entrepreneurs must manage and maintain the reputation of their restaurant so that consumer confidence is maintained.

Food and beverages are listed as one of the business potentials with high growth rates. This is because food is one of the main needs of all people from all walks of life. One sector that is currently growing rapidly is the fast food business. Fast food is food and drinks that can be consumed directly, such as pizza, sandwiches and chicken-based foods (Goyal and Singh, 2007). Fast food is a fast food alternative that is affordable and available for cooking at home (Adam, 2005).

The culinary business is a form of creative business that is in great demand by the public. Many new entrepreneurs offer recreation businesses, tourism park

interesting ideas related to restaurant concepts. According to the latest data from the Central Statistics Agency published by the Ministry of Tourism (2014), the development of the restaurant business from 2008 to 2011 increased from 2,235 business units to 2,977 business units. This proves that the culinary business, in Indonesia, is one of the businesses with fierce competition. What is of concern is that the form of a local restaurant business in Indonesia, which was originally single, has now developed into a chain restaurant. With the increasing number of chain-based local restaurant brands in Indonesia, it shows that consumer preferences have now shifted from restaurant brands that offer non-local menus to local menus.

The taste of a food and the quality of service are important things that are usually considered by many people in choosing a place to eat, and the supporting factors in its selection are the cleanliness and health of food. Business development in the field of Food and Beverage (F\&B) in Indonesia still has good opportunities until now. In Indonesia, there are still quite a lot of innovations that can be explored in this field of Food and Beverage. So, consumers are required to choose intelligently. In addition, consumers are also given the advantage of a wide variety of choices due to the impact of the increasing number of players in this market. What needs to be considered in the Food and Beverage business is the development of the needs and desires of the community itself, apart from covering prices that are affordable, safe for consumption, practical, and others.

Employees as human resources owned by a restaurant occupy a strategic position in a company among other resources, so that in order to produce output in accordance with company expectations, human resources should be managed and utilized properly. Often the Copyright @ 2020, Publik (Jurnal Ilmu Administrasi), ISSN: 2301-573X (Print), ISSN: 2581-2084 (Online) 
problems related to human resources continue to increase, especially those related to the supply of skilled labor, have high adaptability, and are able to deal with ambiguity or confusion that occurs. Human resources have a big share in the success of a business, especially if these human resources are ready to use and have experience. However, companies also cannot determine with certainty how to recruit, retain, and motivate an increasingly diverse human resource. Apart from this, companies are often constrained by how to find individuals who have the right skills, knowledge and abilities. It all ultimately boils down to how to direct existing human resources so that they can become a source of competitive advantage.

Barru Regency as one of the regencies in South Sulawesi is one of the strategic locations to establish a restaurant or culinary business, especially seafoodbased foods. Barru Regency has a high number of potential consumers for culinary products. This is also supported by the location of Barru Regency which has many tourist objects so that tourists continue to be visited every day. Seeing this potential, many restaurant entrepreneurs in Barru District have set up local restaurants. To be able to make a difference, restaurant entrepreneurs offer uniqueness in terms of products. Local restaurateurs offer specialized products. Some of the superior products offered by local restaurants are processed seafood such as fish, shrimp, crab and shellfish as well as chicken and duck.

The mindset of modern society regarding the need for food has begun to shift. The need for food is no longer considered a basic need but a part of the lifestyle. Moreover, modern people who have high mobility tend to prefer practical food. This condition is a great opportunity for fast food restaurants to compete to offer fulfillment of practical food needs. With the increasing number of fast food restaurants that are developing in Barru Regency, it creates fierce competition between restaurants, especially restaurants that offer similar menus. Business owners are required to have superior facilities and services according to consumer needs in order to maintain their existence. Fast food business owners need to know the factors that influence purchasing decisions so that they can affect customer satisfaction, including restaurant atmosphere, service quality, product quality and product prices.

Good service quality is closely related to customer satisfaction, because when customers are not satisfied with the service they receive, they can move to another restaurant. But if customers are satisfied with the service they receive, they will remain loyal to the restaurant and can establish long-term relationships with their customers. In addition, satisfied customers will tell others about the good experiences they had during their stay at a particular restaurant.

There is no business that can survive if it cannot market its products well. No matter how perfect business management is, if it is not accompanied by the ability to market goods and services, the business will go into bankruptcy (collaps). On the other hand, if a business is able to increase sales volume / turnover, the business has the possibility to continue its business (Nitisemito, 1995). In overcoming this problem, the marketing strategy applied by a business must pay attention to various environmental factors, both internal and external, which are constantly changing. A good marketing strategy requires a knowledge of what is being asked by consumers so that the company can make adjustments to these desires. 
The importance of the restaurant atmosphere has been expressed by a number of researchers. Various studies have shown a significant effect of the quality of the restaurant atmosphere on consumer satisfaction. Research conducted by Babin et al., (2005) confirmed that the physical environment plays a strong role in influencing positive relationships with. The results of research by Arifin et al., (2011) revealed that the atmospheric conditions of a restaurant such as color, design, lighting and layout had a significant effect on consumer behavior. The same thing was expressed by Ryu and Han (2010) that the physical environment has a significant effect on customer satisfaction.

Even the research results of Pecotić, Bazdan and Samardžija (2014) reveal that consumers are willing to pay more to get better interior design conditions. However, different research results revealed by Andaleeb and Conway (2006) that the design and physical appearance of a restaurant have no significant effect on customer satisfaction. From some of the results of this study, it is very interesting to examine how the role of the atmosphere of fast food restaurants on purchasing decisions and consumer satisfaction. Service quality plays an important role in customer satisfaction (Yusoff et al., 2010; Pride and Ferrel, 2010; Saidani et al., 2013; Aryanti et al., 2013).

Malik et al., (2013) revealed that the components of service quality such as employee appearance, physical appearance and food quality have a significant effect on customer satisfaction. The results of research by Ryu and Han (2010) state that service quality plays a significant role in customer satisfaction at restaurants. Even the results of Andaleeb and Conway's (2006) research reveal that service quality is the most important factor in influencing purchasing decisions and satisfaction, Copyright (c) 2020, Publik (Jurnal Ilmu Administrasi), ISSN: 2301-573X (Print), ISSN: 2581-2084 (Online) followed by price and product quality. This study aims to describe the strategies used in increasing restaurant guest visits in Barru Regency.

\section{RESEARCH METHOD}

The research method used in this research is descriptive quantitative research method, which is a method of examining the status of an object, a group of people, a system of thought, a set of conditions, or a class of current events by making a systematic, factual and accurate description or description. regarding the properties or facts as well as the relationship between the phenomena being investigated with the correct interpretation (Nazir, 2005).

\section{RESULT AND DISCUSSION \\ Visiting Guest Enhancement Strategy}

The restaurant in Barru Regency offers a variety of food menus and drinks. The types of drinks consist of various Fresh juice, Shake, Fresh \& Tea, Softdrink, Punch, and Coffee. The food and drinks served by this restaurant are of good quality as seen from the quality raw materials, good taste and attractive appearance. This restaurant always tries to provide the best service for the convenience and satisfaction of consumers.

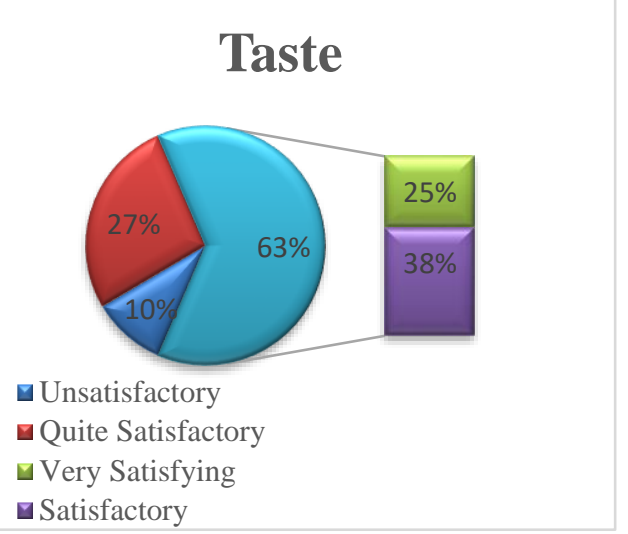

\section{Picture 1}

Based on the Picture 1, it is known that the strategy carried out by the restaurant management in Barru Regency 
is to improve the taste of food. This is evidenced by $38 \%$ of respondents said the taste of the restaurant in Barru district was satisfactory, $27 \%$ said it was quite satisfying, $25 \%$ said it was very satisfying and $10 \%$ said it was not.

Furthermore, another thing that influences consumer assessment of a product other than taste is the freshness of the raw materials used in food processing.

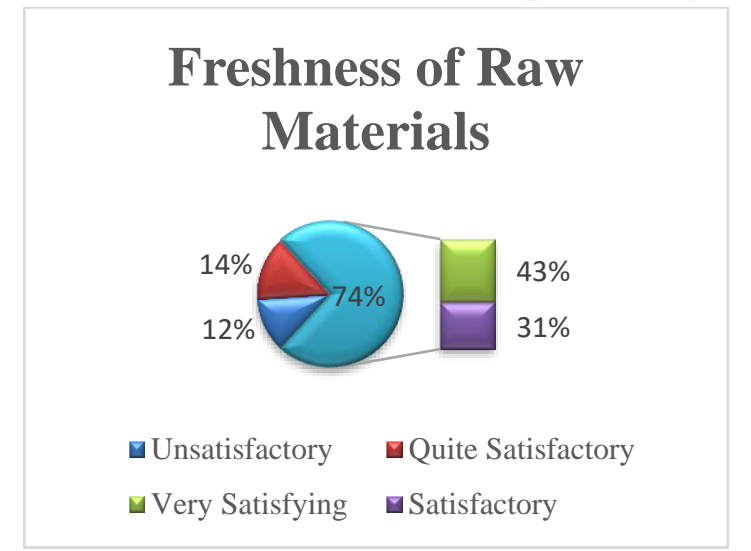

\section{Picture 2}

In maintaining the quality of food, of course, raw materials are the main measure, the freshness of the raw materials used of course will affect the taste of the food cooked for that. Restaurants in Barru Regency always maintain the freshness of the raw materials they use. Based on the Picture 2, it is known that $42 \%$ of respondents said they were very satisfied with the freshness of raw materials, $32 \%$ said they were satisfactory, $14 \%$ said they were quite satisfied and $12 \%$ said they were not.

Furthermore, after maintaining the freshness of the raw materials used, the variety of food also affects the level of guest visits, the more variety of food available, the more interested guests will be to come because they have many food choices. A Picture data of food variations is presented.

\section{Variety of Food}

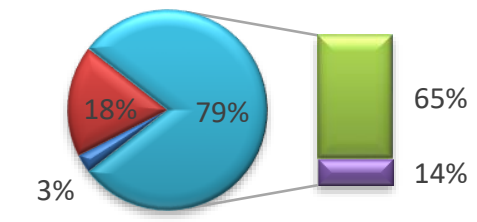

$$
\begin{array}{ll}
\boldsymbol{\nabla} \text { Unsatisfactory } & \boldsymbol{\nabla} \text { Quite Satisfactory } \\
\square \text { Very Satisfying } & \boldsymbol{\square} \text { Satisfactory }
\end{array}
$$

\section{Picture 3}

Based on the Picture 3, it is known that the food variation at Barru's restaurant, $65 \%$ of respondents said it was very satisfying, $18 \%$ said it was quite satisfying, $14 \%$ said it was satisfactory and 3\% said it was unsatisfactory. Furthermore, after there are many variations in food, what is taken into consideration is the variation in food portions.

\section{Food Portion}

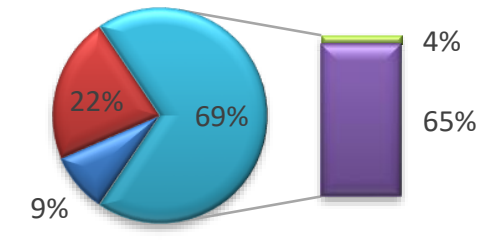

$$
\begin{aligned}
& \text { घUnsatisfactory } \mathbf{Q} \text { Quite Satisfactory } \\
& \square \text { Satisfactory } \square \text { Very Satisfying }
\end{aligned}
$$

\section{Picture 4}

Based on the Picture 4, it is known that $65 \%$ of respondents said that the variation of food portions was very satisfying, 22\% said it was satisfactory, 9\% said it was not satisfactory and $4 \%$ said it was satisfactory.

Furthermore, this food variation, of course, consists of two menus, namely variations in food and beverages. The table below will present data on food and beverage variations. 


\section{Menu Variations}

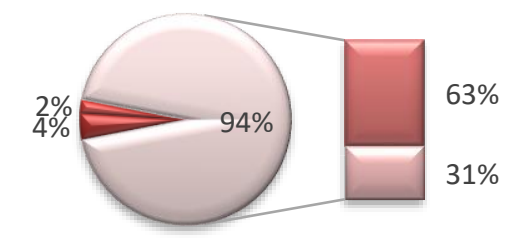

घUnsatisfactory Quite Satisfactory

$\square$ Very satisfying $\square$ Satisfactory

\section{Picture 5}

Based on the Picture 5 , it is known that $62 \%$ of respondents said that the variety of food and beverage menus was very satisfying, $31 \%$ said it was satisfactory, $4 \%$ said it was not satisfactory and $2 \%$ said it was quite satisfying.

In addition to the many variations in the food and beverage menu offered by restaurants, halal is an important element of consumer judgment. Halal menu can be seen in the next Picture;

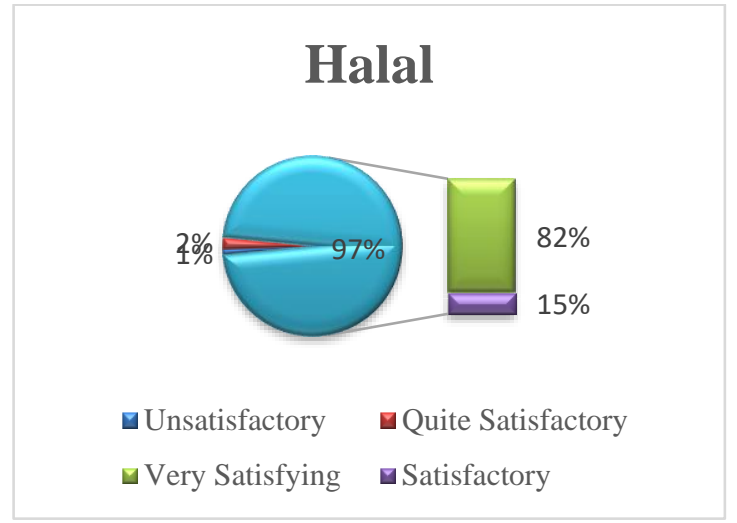

Picture 6

Based on the Picture 6, it is known that $82 \%$ of respondents admit that the halal indicator on the menu served at the Barru district restaurant is very satisfying, $15 \%$ say it is satisfactory, $2 \%$ say it is quite satisfying and $1 \%$ admit it is not satisfactory.

Furthermore, after customers feel sure about the halalness of food in a restaurant, another consideration is the price issue. Below is presented a table regarding the prices offered by the restaurant;

\section{Price Offered}

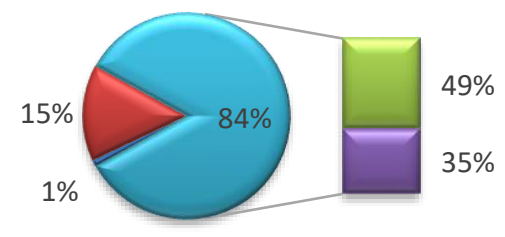

$\square$ Unsatisfactory $\square$ Quite Satisfactory

$\square$ Very Satisfying $\square$ Satisfactory

\section{Picture 7}

Based on the Picture 7, it is known that the price offered by the restaurant to customers is $49 \%$ admitting that the price is very satisfying, $35 \%$ claiming to be satisfactory, $15 \%$ claiming to be quite satisfying and $1 \%$ claiming to be unsatisfactory.

Furthermore, after the price of food and drink, location is also an important thing to study. The easier the location of a restaurant to be reached, the easier it will be to attract customers to come.

\section{Restaurant location}

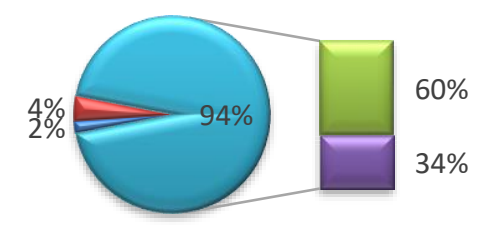

$$
\begin{array}{ll}
\square \text { Unsatisfactory } & \square \text { Quite Satisfactory } \\
\square \text { Very Satisfying } & \square \text { Satisfactory }
\end{array}
$$

\section{Picture 8}

Based on the Picture 8, it is known that $60 \%$ of respondents claim to be very satisfied with the location of the restaurant in Barru district because access to the restaurant is very easy to reach and its strategic location, $34 \%$ claim to be satisfactory, $4 \%$ claim to be quite satisfying and $2 \%$ admit that they are not satisfied.

Furthermore, after the location, what is taken into consideration by guests is the speed of the presentation. This is very 
crucial because of the long waiting time because the slow serving of food will affect the mood of the guests. The table below presents the data serving speed;

\section{Serving Speed}

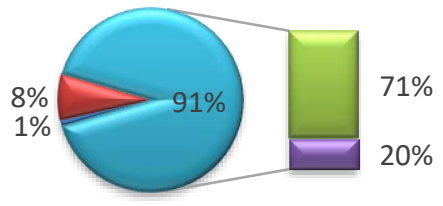

$\square$ Not satisfactory $\square$ Good enough

$\square$ Very satisfy $\square$ Satisfactory

\section{Picture 9}

Based on the Picture 9, it is known that $71 \%$ of respondents said they were very satisfied with the speed of serving, $20 \%$ said they were satisfactory, $8 \%$ said they were quite satisfying and $1 \%$ said they were not.

Furthermore, after the speed of serving, the waiters' alertness in serving customers greatly affects the intensity of increasing the guest visits of the restaurant as presented in the next Picture.;

\section{Waiter Alert}

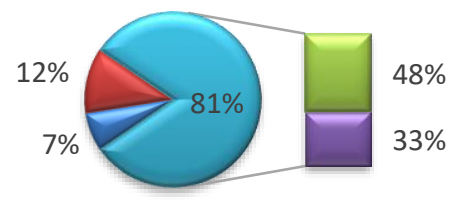

$$
\begin{aligned}
& \square \text { Not satisfactory } \square \text { Good enough } \\
& \square \text { Very satisfy } \quad \square \text { Satisfactory }
\end{aligned}
$$

\section{Picture 10}

Based on the picture 10, it is known that $48 \%$ of the respondents said that the waitresses were very satisfying, $33 \%$ said they were satisfactory, $12 \%$ said they were quite satisfying and $7 \%$ said they were not. Furthermore, after service from weiters alacrity, knowledge of the menu offered by the restaurant is also the basic knowledge that weiters must know so that it is easy to offer and provide explanations to customers. Below is presented a table of service knowledge regarding the menu offered by the restaurant;

\section{Menu Knowledge}

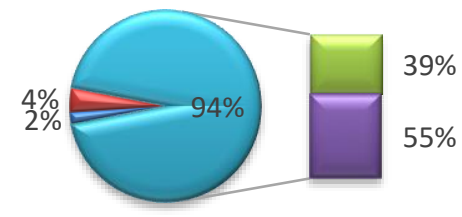

曰 Not satisfactory $\mathbf{\square}$ Good enough

$\square$ Very satisfy $\square$ Satisfactory

\section{Picture 11}

Based on the picture 10, it is known that $55 \%$ of respondents said they were satisfied with the knowledge and explanations provided by the waiter regarding menu information, 39\% admitted that they were very compelling, $4 \%$ claimed to be quite satisfying and $2 \%$ claimed they were not satisfactory.

Next, the picture 12 regarding the friendliness and politeness of the waiters is presented in the next picture;

\section{Friendliness and Courtesy}

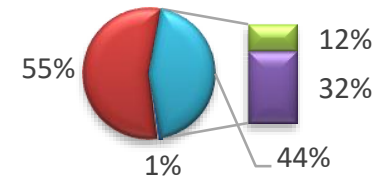

$$
\text { घNot satisfactory } \mathbf{\square} \text { Good enough }
$$$$
\square \text { Very satisfy } \square \text { Satisfactory }
$$

\section{Picture 12}

Based on the picture 12, it is known that $55 \%$ of respondents said the friendliness and politeness of the waiter was satisfactory, $32 \%$ said it was satisfactory, $12 \%$ said it was very satisfying and $1 \%$ said it was not satisfactory. Furthermore, after the attitude of hospitality and politeness of the waiter towards guests, their ability to deal with 


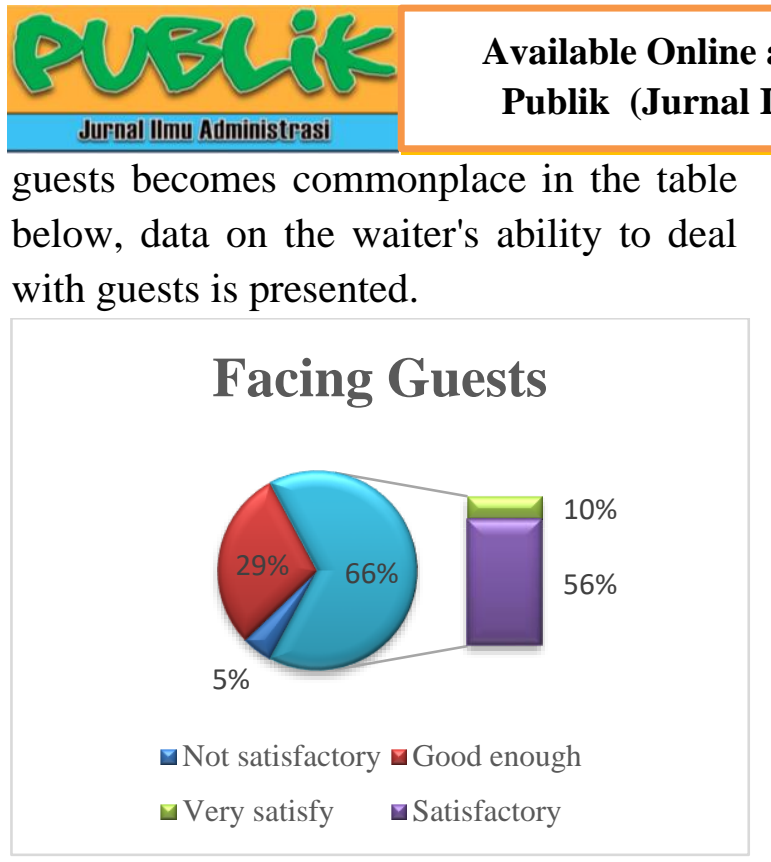

\section{Picture 13}

Based on the picture 13, it is known that $56 \%$ of respondents said the ability of waiters at the Barru Regency restaurant in dealing with guests was satisfactory, 29\% said it was satisfactory, $10 \%$ said it was very satisfying and 5\% said it was not satisfactory. Furthermore, after all services are obtained by consumers properly, the public facilities provided by the restaurant must be reviewed. Below is presented a picture regarding public restaurant facilities in Barru Regency.

\section{Public facilities}

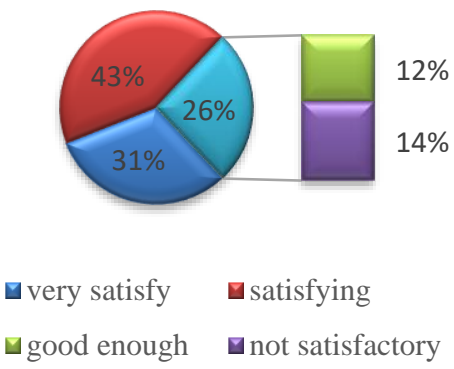

\section{Picture 14}

Based on the picture 14, it is known that $43 \%$ of respondents said the public facilities provided by the restaurant were satisfactory, $31 \%$ said they were very satisfying, $14 \%$ said they were unsatisfactory and $12 \%$ said they were satisfactory. These public facilities are related to prayer rooms and toilets for guests and employees. Furthermore, the factor that affects the increase in restaurant guest visits is the convenience that guests get. Restaurant comfort is presented in the picture 15 :

\section{Restaurant Convenience}

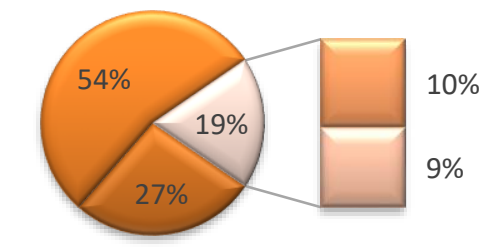

$$
\begin{aligned}
& \square \text { very satisfy } \square \text { satisfying } \\
& \square \text { good enough } \square \text { not satisfactory }
\end{aligned}
$$

\section{Picture 15}

Based on the picture 15, it is known that $54 \%$ of respondents said the convenience of the restaurant was satisfactory, $27 \%$ said the comfort of the restaurant was very satisfying, $10 \%$ said it was satisfactory and $9 \%$ said the comfort of the restaurant was not satisfactory.

\section{Restaurant Cleanliness}

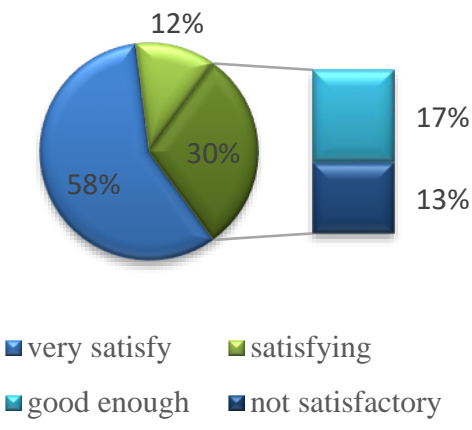

\section{Picture 16}

Based on the picture 16, it is known that $58 \%$ of respondents said the cleanliness of the restaurant was satisfactory, $17 \%$ said it was very satisfying, $13 \%$ said it was not satisfactory and $12 \%$ said that the cleanliness of the restaurant in Barru Regency was satisfactory. The cleanliness of the room, floors and tables in the Barru Regency restaurant looks less clean as expressed by one of his customers, in terms of cleanliness of the floor so that it can be 
cleaner and more sleek when visitors come (interview: Umm Latifah, 2 August 2019).

This can provide an uncomfortable atmosphere for customers who come. For employees who are assigned to maintain cleanliness, they must do more when carrying out the duties and responsibilities that have been given to them.

Furthermore, after the cleanliness of the restaurant, the appearance of the restaurant is a consideration for guests and restaurant entrepreneurs in increasing the intensity of the visit. Below is presented the restaurant display picture 17:

\section{Restaurant View}

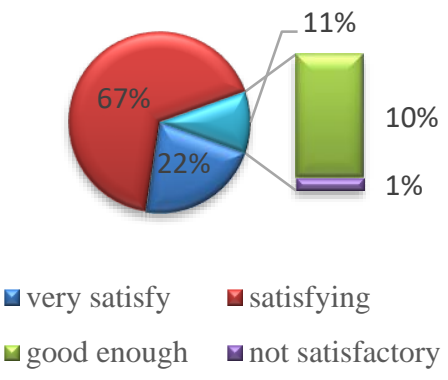

\section{Picture 17}

The appearance of the restaurant is related to the interior design and layout of the restaurant so that guests feel comfortable eating in that place. Based on the picture 17 , it is known that $67 \%$ of respondents said the appearance of the restaurant was satisfactory, 225 said that the restaurant menu was very satisfying, $10 \%$ of respondents said it was quite satisfying and $1 \%$ said it was not satisfactory.

Furthermore, after the appearance of the restaurant, the music that accompanies the guests to eat also contributes to increasing guest visits. Below is presented a data of music.

\section{Music}

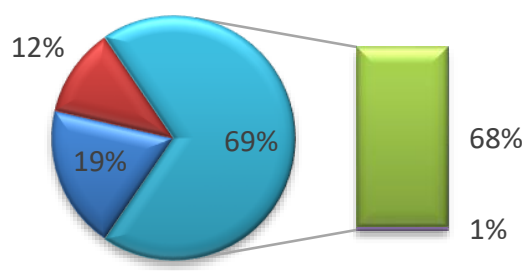

a very decisive $\mathbf{s}$ satisfying

$\square \operatorname{good}$ enough $\boldsymbol{\square}$ not satisfactory

\section{Picture 18}

Based on the picture 18, it is known that $68 \%$ of respondents said the music in the Barru district restaurant was quite satisfying, $19 \%$ of respondents said it was very satisfying, $12 \%$ of respondents said the music was satisfying and $1 \%$ said the music was unsatisfactory.

Furthermore, the facilities that are no less important that must be available are restored and are always taken into consideration, namely parking facilities. Below is presented a data of customer / guest satisfaction on the availability of parking facilities.

\section{Parking Facilities}

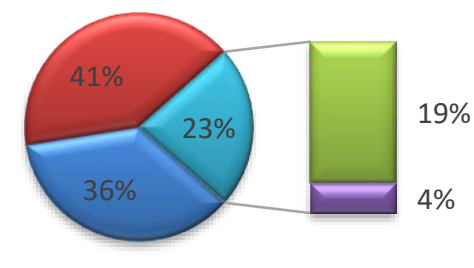

$$
\begin{aligned}
& \boldsymbol{\nabla} \text { very satisfy } \quad \boldsymbol{\square} \text { satisfying } \\
& \boldsymbol{\nabla} \text { good enough } \quad \boldsymbol{\square} \text { not satisfactory }
\end{aligned}
$$

\section{Picture 19}

Based on the picture 19, it is known that $41 \%$ of respondents said the parking advice provided by the restaurant was satisfactory, $36 \%$ said it was very decisive, $19 \%$ said it was quite satisfying, and $4 \%$ said $4 \%$ because they felt it was still difficult to park their vehicle. 


\section{Available Online at http://journal.umgo.ac.id/index.php/Publik \\ Publik (Jurnal Ilmu Administrasi) Vol 9 (2), Desember 2020}

Furthermore, after parking facilities, restaurant lighting is also important. The illumination of the restaurant can affect the bias of the light produced and the atmosphere displayed. Restaurant lighting also has to do with security. Below is presented data regarding restaurant lighting;

\section{Restaurant Lighting}

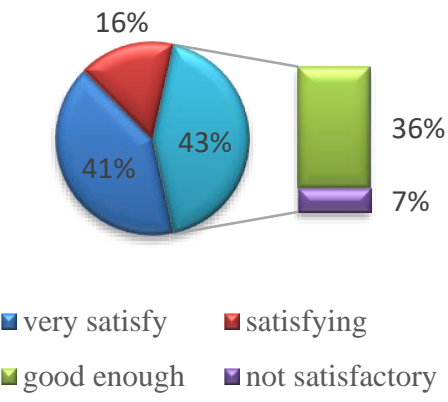

Picture 20

Based on the picture 20, it is known that $44 \%$ of respondents said the restaurant lighting was very satisfying, $38 \%$ said it was quite satisfying, $17 \%$ said it was satisfactory and $1 \%$ said the restaurant lighting was not satisfactory.

Furthermore, in increasing restaurant visits, it is necessary to collaborate with various parties or related agencies. This is very important so that the restaurant has regular customers. Below is presented data about the cooperation carried out by the restaurant.

\section{Increased Cooperation}

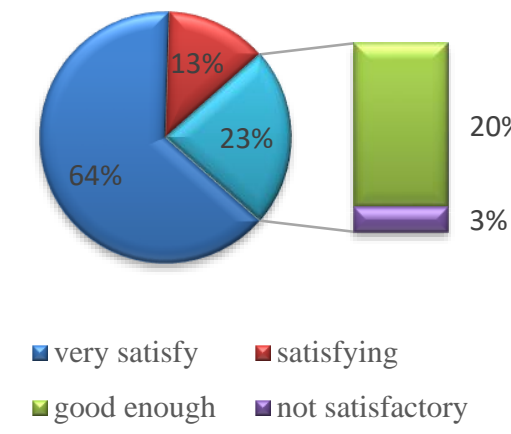

Picture 21
Based on the picture 21, it is known that in order to develop restaurants and increase visiting guests, the restaurant management has increased cooperation with various parties, $64 \%$ of respondents said the increase in cooperation was very compelling, $20 \%$ of respondents said it was quite satisfying, $13 \%$ said it was satisfactory, and $3 \%$ said it was not satisfying.

Furthermore, after increasing cooperation it is necessary to take further action such as promotion. Below is presented a data regarding restaurant promotions.

\section{Restaurant Promotion}

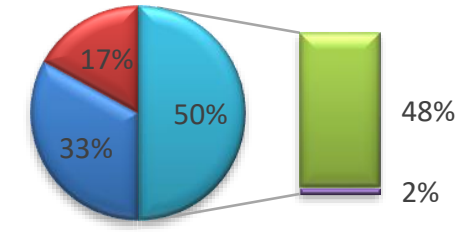

$$
\begin{aligned}
& \boldsymbol{\nabla} \text { very satisfy } \quad \mathbf{m} \text { satisfying } \\
& \square \text { good enough } \quad \mathbf{m} \text { not satisfactory }
\end{aligned}
$$

\section{Picture 22}

Based on the data in picture 22 , it is known that $48 \%$ of respondents admitted to being quite satisfied with restaurant promotions carried out with the management, $33 \%$ admitted that they were very satisfying, $17 \%$ claimed to be satisfying and $2 \%$ admitted that they were not satisfied with restaurant promotions.

\section{IFE Matrix}

Internal factor identification aims to classify the factors which are the strengths and weaknesses of the company. The identification results show that the Barru Regency restaurant has five strengths and four weakness, the strength are: (1) The menu served at the Barru Regency restaurant has great taste, which is unique because the chicken and seafood 
processing is done by the owner using selected spices that have been tested. (2) Supervision of the quality of restaurants in Barru Regency is carried out strictly by going through a process of selecting quality raw materials and seasonings sent directly from the center. This is done so that the resulting menu has a delicious taste and is able to bind their customers. (3) Quality human resources owned by Barru Regency restaurants. The employees of this restaurant are their chosen employees, the better the day they will be in terms of providing services to their customers. (4) Products owned by the Barru Regency restaurant, in this case the products. food menu, already has 47 menus. Most of the modifications of pre-existing dishes. So that the menu served is not just chicken, but there are fish, vegetables, and juices. (5) The sales system carried out by the Barru Regency restaurant is to establish as many branches or representatives as possible. Until now, Barru Regency restaurant has several branches, this is done so that consumers who have subscribed.

While the four weaknesses include: (1) The product is not durable. As with other ready-to-eat food products, the menu at Barru Regency restaurants also has a non-durable nature. (2) The management of the Barru Regency restaurant is currently not actively promoting. (3) A management system that is still in the form of a kinship. The leadership is held by the absolute owner. (4) Promotional discourse raised by restaurant owners in Barru Regency tends to be passive.

\section{External Environmental Analysis}

External environmental analysis aims to identify and evaluate trends and events that are beyond a restaurant's control. External environmental analysis focuses on determining key factors which is a threat and opportunity for restaurants, making it easier management to determine strategies to seize opportunities and avoid threat. External environment analysis consists of micro and macro environmental.

\section{Micro Environment}

The micro environment consists of direct influencers the restaurant's ability to market its products. Micro environment can also called the external environment which has a direct impact on the restaurant. The micro environment consists of: suppliers, customers and competitors. (a) Suppliers, Especially for seafood raw materials for the seafood menu at the Barru Regency restaurant, it is imported from the surrounding area with the agreed size and quality. Apart from chicken and other raw materials, additional products such as spices and fruits are also imported from the barru area and so on. (b) Customer, the customers of restaurants and restaurants in Barru County are treated like brothers, trying to get to know their names so that the customer relationship feels close. The waiters in the restaurant always try to know the names of customers in various ways. This is done with the aim that customers come not only as buyers but also as friends. Another thing that is done to customers is to always ask about their complaints so far. Approximately 70 percent of restaurant customers are still loyal to this day. (c) Competitor, Competitors from restaurants in Barru Regency, namely the number of restaurants and restaurants being built, the difference in prices offered and the menu innovation of each restaurant and restaurant are challenges for each restaurant and restaurant.

\section{Macro Environment}

Macro environment or what is often called the external environment has strategic impact for restaurants. The macro 


\section{Available Online at http://journal.umgo.ac.id/index.php/Publik \\ Publik (Jurnal Ilmu Administrasi) Vol 9 (2), Desember 2020}

environment consists of the greater social power that affects all actors in the environment micro restaurant, namely: demographic, economic, technological, legal and political factors as well as socioculture.

\section{Demographic factors}

The growth of the population of Barru Regency which is quite large with a growth of 2.4 percent per year has opened up opportunities for restaurants if it is followed by efforts to increase the consumption of chicken and seafood. This also has a positive impact on increasing the potential for restaurant market opportunities.

\section{Economic factors}

The income per capita of the residents of Barru Regency is $\mathrm{Rp}$. $2,700,000$ is one of the factors that affect the level of purchasing or purchasing power of the community. Given that seafood and chicken are a menu that has a high selling value in the food market in Indonesia.

\section{Socio-cultural factors}

The increasing knowledge of humans about the virtues of consuming nutritious food, the more people will consume foods with good nutritional content. Chicken and seafood is one of the typical food menus for Indonesians. For example, this menu is served in various ways / readiness in celebration of religious holidays, chicken and seafood are one of the favorite menus. In certain celebrations, for example weddings, birthdays, and others, there are always chicken and seafood menus.

\section{Technological factor}

When restaurants and restaurants in Barru Regency receive an order that must be delivered, the order is wrapped in a coating that can keep the food warm, which has strength for $1 \times 24$ hours, so that it maintains the taste when it reaches consumers, while in beverage processing Copyright @ 2020, Publik (Jurnal Ilmu Administrasi), ISSN: 2301-573X (Print), ISSN: 2581-2084 (Online) done with a juicer (juice maker) this is done to speed up the presentation.

\section{Political factors and government policies}

Restaurant and restaurant businesses that are not included in primary needs are predicted to be sufficiently affected to face the 2020 economic conditions which are marked by the food crisis and the increase in the price of staples which will decrease people's purchasing power. Deteriorating economic conditions marked by the food crisis and rising prices for basic commodities had an increasingly real impact. This is not only felt in businesses engaged in the culinary sector such as restaurants and restaurants.

\section{CLOSING}

\section{Conclusion}

The marketing strategy carried out by restaurants in Barru Regency is mainly related to the $4 \mathrm{P}$ marketing mix that is right and running well, the conclusion that can be drawn from the analysis of the marketing strategy of each restaurant marketing mix in Barru Regency is that each marketing mix such as product, price, place, promotion, has shown conformity with the segmentation, targeting and positioning expected by the restaurant. For example, a product offered varies and uses quality raw materials according to positioning the company wants to achieve as the only restaurant using healthy chicken and seafood raw materials

\section{Suggestion}

Prices, physical evidence and promotions are also in line with the targeting of young people and families, because of the price offered is still quite affordable, the place is also unique and promotional through online media. Restaurants in Barru Regency must make consumers comfortable for a long time enjoying the menu served so that it needs to be maintained to overcome competitors 
from new and old newcomers in the restaurant industry in Barru Regency and there is a need for improvements in other types of services such as speeding up the menu served. to consumers so that consumers are satisfied.

\section{REFRENCES}

Adams, R. (2005). Fast food, obesity and tort reform: an examination of industry responsibility for public health. Business and Society Review, 110(3), 297-320.

Ariffin, H.F., Bibon, M.F., \& Abdullah, R.P.S. R, (2011). Restaurant's atmospheric elements: what the customer wants. Journal of Asian Behavioural Studies, 1(2), 33-43.

Aryanti, D., Hudoyo, A., \& Kaymir, E, (2013). Analisis tingkat pelayanan restoran terhadap kepuasan pelanggan: studi kasus pada dua restoran di kompleks pertokoan way halim permai kota Bandar Lampung. Journal of Agribusiness Science, 1(2), 118-125.

Babin, B.J., Lee, Y., Kim, E., Griffin, M, (2005). Modeling consumer satisfaction and word-of-mouth: restaurant patronage in Korea. Journal of Services Marketing. 19(3), 133-139.

BPS. (2017). Kabupaten Barru Dalam Angka Tahun 2017. Badan Pusat Statistik.

Goyal, A. \& Singh, N. P, (2007). Consumer perception about fast food in India: an exploratory study. British Food Journal, 109(2), 182-195

Kementerian Pariwisata. (2014). Perkembangan Usaha Restoran/
Rumah Makan Berskala Menengah dan Besar Menurut Provinsi. [Online] Tersedia di: http:// www.kemenpar.go.id/asp/ringkasan. asp?c=114 [Diakses 2 Februari 2019].

Malik, S.A., Jaswal, L.H., Malik, S.A. \& Awan, T.M, (2013). Measuring service quality perceptions of the customers of restaurant in Pakistan. International Journal for Quality Research, 7(2), 187-200.

Nasir, M. (2005). Metodelogi Penelitian. Jakarta: Ghalia Indonesia.

Nitisemito, A. (1995). Manajemen Pemasaran. Jakarta: Ghalia Indonesia.

Ryu, K., \& Han, H. (2010). Influence on the quality of food, service, and physical environment on customer satisfaction and behavioral intention in quick-casual restaurants: moderating role of perceived price. Journal of Hospitalityand Tourism Research. 34(3), 310-329.

Saidani, B., Rachman, M. A. \& Rizan, M, (2013). Pengaruh kualitas produk dan desain produk terhadap keputusan pembelian sepatu olahraga futsal adidas di wilayah Jakarta Timur. Jurnal Riset Manajemen Sains Indonesia, 4(2), 201-217.

Syahrial, S., \& Badollahi, M. Z. (2020). Development of a Community-Based Marine Tourism Attraction in the Samboang Beach in Bulukumba Regency. Journal La Bisecoman, 1(2), 1-9.

Yusoff, W. Z. W., Ismail, M. \& Ali, A.S. (2010). Understanding the services 
provider perspective towards better service quality in local authorities.

Journal of Facilities Management, 8(3), 226-230. 